\title{
ПРИНЦИП СОСТЯЗАТЕЛЬНОСТИ В ПРОИЗВОДСТВЕ ПО ДЕЛАМ ОБ АДМИНИСТРАТИВНЫХ ПРАВОНАРУШЕНИЯХ В ОБЛАСТИ АНТИМОНОПОЛЬНОГО ЗАКОНОДАТЕЛЬСТВА И ПРОБЛЕМЫ ЕГО РЕАЛИЗАЦИИ НА СТАДИИ РАССМОТРЕНИЯ ДЕЛА О НАРУШЕНИИ АНТИМОНОПОЛЬНОГО ЗАКОНОДАТЕЛЬСТВА КОМИССИЕЙ АНТИМОНОПОЛЬНОГО ОРГАНА
}

\begin{abstract}
Аннотация: Статья посвящена анализу действию в производстве по делам об административных правонарушениях принципа состязательности, который выступает эффективным средством защиты прав и законных интересов лии, привлекаемых к административной ответственности. Особое внимание автор уделяет проблемам реализации данного принципа в производстве по делам об административных правонарушениях в области антимонопольного законодательства. Автор анализирует действующее законодательство, регламентирующее порядок привлечения к административной ответственности за нарушения антимонопольного законодательства, на предмет его соответствия правилам состязательного процесса. Метод и методология исследования основываются на аккумулировании общенаучных и частнонаучных способов и приемов, используемых в целом юридической наукой, а именно: диалектический, исторический, структурно-системный, сравнительно-правовой, статистический, формально-логический, анализ, системный метод. Научная новизна настоящего исследования обусловлена тем, что автором предпринята попытка проанализировать влияние действия принципа состязательности на производство по делам об административных правонарушениях, выявить проблемы реализации принципа состязательности при осуществлении уполномоченными органами исполнительной власти административно-юрисдикционного процесса, в частности, при рассмотрении дела о нарушении антимонопольного законодательства Комиссией антимонопольного органа.

Ключевые слова: состязательность, процесс, принципы, антимонопольное регулирование, административное правонарушение, административная юрисдикция, административный процесс, доказывание, проблемы реализации, принцип состязательности.

Review: The article is devoted to the analysis of the principle of competitiveness in the proceedings on administrative offences. The author pays special attention to the problems of implementation of this principle in the proceedings on administrative offences in the sphere of antimonopoly legislation. The methodology of the study is based on accumulation of general and special scientific methods and techniques used in juridical science in general, namely the dialectical, historical, structural and systematic, comparative legal, statistical, formal and logical analysis and the system method. The scientific novelty of this study lies in the fact that the author attempts to analyze the influence of the principle of competitiveness on the proceedings on administrative offences cases as well as to identify the problems of implementation of the principle of competitiveness during the implementation of administrative-jurisdictional process by the authorized bodies of executive power, in particular when considering the antitrust legislation violation case by the Commission of the Antimonopoly body.
\end{abstract}

Keywords: administrative process, administrative jurisdiction, administrative offence, antimonopoly regulation, principles, process, compettitiveness, proof, problems of implementation, principle of competitiveness.

$\mathrm{H}$ а сегодняшний день вопрос перечня принципов, действие которых распространяется на производство по делам об административных правонарушениях, по-прежнему остается открытым ввиду отсутствия единой точки зрения по данному вопросу среди специалистов в области административного права.
КоАП РФ к числу принципов производства по делам об административных правонарушениях относит: принцип назначения только предусмотренных законом мер административной ответственности, принцип презумпции невиновности, принцип равенства перед законом, принцип обеспечения законности при применении мер административного 
принуждения в связи с административным правонарушением, принцип национального языка ведения производства, принцип открытого рассмотрения дел об административных правонарушениях.

Данные принципы являются едиными как для судебного, так и административного порядка рассмотрения дел об административных правонарушениях.

Помимо закрепленных на нормативном уровне принципов в числе принципов административного процесса называют: принцип обязательного участия сторон и выслушивания участников спора, принцип проверки представленных доказательств, принцип инстанционности, принципы непосредственности, диспозитивности, состязательности, недопустимости поворота к худшему, индивидуализации наказания, обеспечения права на защиту и ряд других.

В свою очередь, действие в административном процессе принципа состязательности признается не всеми специалистами.

Сторонники исключения состязательности из числа процессуальных принципов исходят из того, что по свой природе административный процесс относится к инквизиционному типу процесса, в котором суд занимает активную позицию координатора правоотношений, а признание состязательности процесса неразрывно связано с пассивной созерцательностью суда, что противоречит правовой природе государственного органа и самому существу публичных правоотношений [1].

Некоторые авторы, обосновывая утверждение том, что отдельные судопроизводственные принципы в административно-деликтном судопроизводстве являются излишними, заявляют о необходимости предоставления более слабой стороне в процессе дополнительных процессуальных гарантий ее прав, в связи с чем «... не следует провозглашать действие принципа состязательности и равноправия сторон в административном судопроизводстве» [2].

Как представляется, во многом на такую позицию влияют подходы, которые доминировали в советский период, когда административный процесс воспринимался как управленческая деятельность публичных органов, при этом возможность наличия спора между гражданами и органами власти отрицалась [3].

Однако еще в 70-х годах прошлого столетия отдельные ученые обращали внимание на то, что административной юрисдикции свойственен элемент состязательности [4].
На сегодняшний день большинство административистов также склоняется к мнению, что принцип состязательности, несмотря на то, что напрямую в Кодексе он не поименован, все же присущ производству по делам об административных правонарушениях, хотя его реализация и сопряжена с немалыми сложностями [5].

На исключительное значение принципа состязательности неоднократно обращал внимание и Конституционный Суд РФ, по мнению которого, одной из гарантий права на судебную защиту, в том числе применительно к административному судопроизводству, является закрепленное в ч. 3 ст. 123 Конституции РФ положение об осуществлении судопроизводства на основе состязательности и равноправия сторон, распространяющихся на все стадии административного судопроизводства [6].

Соблюдение судопроизводственных принципов, одним из которых является принцип состязательности, является важнейшей гарантией права на защиту, поскольку именно состязательная форма процесса обеспечивает активность сторон в доказывании обстоятельств, имеющих значение для вынесения законного и обоснованного решения по делу.

Между тем данное конституционное положение не нашло своего надлежащего законодательного развития применительно к производству по делам об административных правонарушениях, осуществляемому квазисудебными органами и судами общей юрисдикции.

Судебно-арбитражная модель административно-деликтного судопроизводства существенным образом отличается от модели, существующей в рамках судов общей юрисдикции.

Субъекты административной юрисдикции, уполномоченные составлять протоколы об административных правонарушениях, признаются Арбитражным процессуальным кодексом РФ стороной в процессе и наделяются равными правами по доказыванию со стороной защиты. Четкое разделение функций обвинения, защиты и юстиции в рамках арбитражного процесса, а также равные права сторон административного преследования и защиты позволяют говорить о существовании состязательной формы административно-деликтного судопроизводства, осуществляемого арбитражными судами.

Очевидно, что различия в процедуре рассмотрения дел судами и арбитражными судами столь существенны, что приходится констатировать нарушение конституционного принципа единства средств судебной защиты, о необходимости соблю- 
дения которого неоднократно высказывался Конституционный Суд РФ.

На сегодняшний день же, судьи и мировые судьи, действуя на основе норм КоАП РФ, являются органами, привлекающими к ответственности, а не защищающими [7], в то время как судебно-арбитражная модель административно-деликтного судопроизводства базируется на принципах состязательности и равенства сторон, оставшихся за рамками КоАП РФ.

Подобное построение процесса наделяет судей излишней активностью при рассмотрении дела, компенсируя обвинительный «вакуум». Совмещение функции обвинения и функции юстиции в рамках судебного органа влечет инквизиционность процесса.

Как справедливо замечает Уполномоченный по правам человека в Российской Федерации В.П. Лукин, фактически сторона защиты в административном процессе противостоит не обвинению, а самому суду. Отсутствие состязательности в настоящий момент может превращать административное правосудие в репрессивный механизм, позволяющий быстро и эффективно реализовывать преследование граждан по своему произволу [8].

Применительно к привлечению к ответственности лиц, нарушивших антимонопольное законодательство, реализация принципа состязательности дополнительно осложняется существующей на сегодняшний день процедурной перегруженностью процесса производства по делам об административных правонарушениях в области антимонопольного законодательства.

Так, поводом к возбуждению дела об административных правонарушениях, предусмотренных рядом статей КоАП РФ, в частности, ст. ст. $14.9,14.31,14.31 ., 14.31 .2,14.32,14.33$ является принятие комиссией антимонопольного органа решения, которым установлен факт нарушения антимонопольного законодательства Российской Федерации.

Следует отметить, что дела о нарушениях антимонопольных статей главы 19 КоАП РФ возбуждаются в общем порядке.

Там поводом к возбуждению дела выступает, в частности, и непосредственное обнаружение должностными лицами, уполномоченными составлять протоколы об административных правонарушениях, достаточных данных, указывающих на наличие события административного правонарушения, и поступившие из правоохранительных органов, а также из других государственных органов, органов местного самоуправления, от общественных объединений материалы, содержащие данные, указывающие на наличие события административного правонарушения, и сообщения и заявления физических и юридических лиц, а также сообщения в средствах массовой информации, содержащие данные, указывающие на наличие события административного правонарушения.

Вышеизложенное позволяет говорить о так называемой дуалистической модель административно-деликтного процесса привлечения виновного лица к административной ответственности. Дуализм заключается в механическом соединении в один процесс двух групп административных процедур. Одна группа установлена в Федеральном законе о защите конкуренции и принятых в соответствии с ним подзаконных актах, другая - в КоАП РФ. Первая закреплена в главе 9 Закона о защите конкуренции, вторая- в процессуальных нормах КоАП РФ о возбуждении и рассмотрении дел об административных правонарушениях. Обе процедуры механически связываются между собой положением ст. 28.1 КоАП РФ, которая устанавливает, что поводом к возбуждению дел по антимонопольным статьям главы 14 КоАП РФ является принятие комиссией антимонопольного органа решения, которым установлен факт нарушения антимонопольного законодательства Российской Федерации.

Анализируя существующий на сегодняшний день процесс привлечения к административной ответственности за нарушение антимонопольного законодательства, ряд авторов указывает, что «наряду с судебным процессом, регулируемым нормами АПК РФ и ГПК РФ при применении и нарушении антимонопольного законодательства, существует еще два самостоятельных процесса, регулируемых разными законами - Законом о защите конкуренции и КоАП РФ» [9].

Однако более обоснованной представляется позиция авторов, которые считают, что де-факто имеет место один процесс, а «обусловленность производства по делу об административном правонарушении проведением особой процедуры рассмотрения дела о нарушении антимонопольного законодательства представляется искусственной конструкцией законодателя, стремившегося, по всей видимости, таким образом обеспечить специфичное рассмотрение столь сложных правоотношений» [10].

В этой связи особое значение приобретают проблемы реализации принципа состязательности на стадии разбирательства в Комиссии антимоно- 
польного органа, поскольку именного решение, вынесенное по результатам данного рассмотрения, имеет основополагающее значение для привлечения лица к административной ответственности.

Административно-юрисдикционный процесс, рассматриваемый как вид юридического процесса, характеризуется различным сочетанием состязательных и инквизиционных начал.

При этом для административно-юрисдикционного процесса, в отличие от уголовного процесca, характерно объединение функций обвинения и разрешения дела в компетенции одного субъекта субъекта административной юрисдикции, а также низкий уровень разработанности и правового закрепления процессуальной функции защиты.

Процедурам, осуществляемым в рамках рассмотрения антимонопольного дела в Комиссии антимонопольного органа, также характерно сочетание элементов состязательного и инквизиционного процессов, что оказывается непосредственное влияние на реализацию в данном процессе принципа состязательности.

Регламентация ключевых административных процедур, регулирующих порядок привлечения к ответственности за нарушение антимонопольного законодательства, получила закрепление в Федеральном Законе «О защите конкуренции».

В частности, глава 9 указанного Закона регламентирует основания возбуждения дел, правовой статус участников процедур, сроки и порядок рассмотрения дел, характеристика принимаемых решений, порядок их исполнения, обжалования и пересмотра.
Кроме того, Закон на нормативном уровне закрепляет порядок формирования и работы Комиссии антимонопольного органа.

Однако данная регламентация указанных процедур не может рассматриваться в качестве гарантии реализации принципа состязательности, поскольку работа Комиссии неразрывно связана с деятельностью антимонопольного органа, который утверждает состав Комиссии и ее председателя, а также принимает мотивированное решение о замене члена комиссии.

Таким образом, реализация принципа состязательности в антимонопольных процедурах ограничена тем, что специально создаваемые состоящие из работников антимонопольного органа комиссии, призванные разрешать дела, не могут обеспечить равенство сторон и состязательность.

В свою очередь, антимонопольный орган может оказывать воздействие на процессуальную деятельность Комиссии посредством утверждения состава комиссии и ее председателя.

Таким образом, к пробелам Федерального Закона «0 защите конкуренции» можно отнести отсутствие в Законе норм, регламентирующих требования к членам Комиссии по рассмотрению антимонопольного дела, а также устанавливающих основания и порядок их отвода, что ограничивает реализацию в производстве по делу о нарушении антимонопольного законодательства принципа состязательности, который, в свою очередь, является эффективным средством защиты прав и законных интересов лиц, привлекаемых к административной ответственности.

\section{Библиография:}

1. Демин А.А. Кодекс административного судопроизводства в РФ или все же Административно-процессуальный Кодекс//Теоретические и практические проблемы административного правосудия.-М.:Международная академия оценки и консалтинга,2006. С.250-259.

2. Симонян С.Л. О проекте Кодекса административного судопроизводства Российской Федерации//Административное право и процесс. 2006.N 1.C.44.

3. Зеленцов А. Административное судопроизводство в России: проблемы правового регулирования. С.85;

4. Попов Л.Л., Шергин А.П. Управление. Гражданин. Ответственность. Л., 1975. С.137.

5. Васильев Ф.П. Доказывание по делу об административном правонарушении: Автореф. дис. ... д-ра юрид. наук. М., 2005. С.25; Панова И.В. Административно-процессуальное право России. М.,2003. С.116; Якимов А.Ю. Принципы административно-юрисдикционного процесса//Государство и право. 1999. N5. C.8.

6. Постановление Конституционного Суда РФ от 14 февраля 2000 г. № 2-П//Вестник Конституционного Суда РФ. 2000. № 3; Определение Конституционного Суда РФ от 12 апреля 2005 г. № 113-0//Российская газета. 31.05.2005. № 114.

7. Панова И.В. Административно-процессуальная деятельность в Российской Федерации. Саратов, 2001. С.48-49.

8. Лукин В.П. Заявление Уполномоченного по правам человека в Российской Федерации // Российская газета. 21.10.2009. № 5023.

9. Конкурентное право России: учебник [Текст]/Д.А. Алешин, И.Ю. Артемьев, Е.Ю. Борзило и др. - М.: Изд. дом Высшей школы экономики, 2012. С.318. 
10. Суменков, С. С. Антимонопольный процесс как квазисудебный административно-юрисдикционный процесс // Бизнес, Менеджмент и Право.-2014.-№ 1.-С.114 - 116.

11. Микулин А.И. Принцип состязательности в производстве по делам об административных правонарушениях. // Административное и муниципальное право.-2010.-10.-С. 64-72.

\section{References (transliterated):}

1. Demin A.A. Kodeks administrativnogo sudoproizvodstva v RF ili vse zhe Administrativno-protsessual'nyi Kodeks// Teoreticheskie i prakticheskie problemy administrativnogo pravosudiya.-M.:Mezhdunarodnaya akademiya otsenki $\mathrm{i}$ konsaltinga,2006. S.250-259.

2. Simonyan S.L. O proekte Kodeksa administrativnogo sudoproizvodstva Rossiiskoi Federatsii//Administrativnoe pravo i protsess. 2006.N 1.S.44.

3. Zelentsov A. Administrativnoe sudoproizvodstvo v Rossii: problemy pravovogo regulirovaniya. S.85;

4. Popov L.L., Shergin A.P. Upravlenie. Grazhdanin. Otvetstvennost'. L., 1975. S.137.

5. Vasil'ev F.P. Dokazyvanie po delu ob administrativnom pravonarushenii: Avtoref. dis. ... d-ra yurid. nauk. M., 2005. S.25; Panova I.V. Administrativno-protsessual'noe pravo Rossii. M.,2003. S.116; Yakimov A.Yu. Printsipy administrativnoyurisdiktsionnogo protsessa//Gosudarstvo i pravo. 1999. N5. S.8.

6. Postanovlenie Konstitutsionnogo Suda RF ot 14 fevralya 2000 g. № 2-P//Vestnik Konstitutsionnogo Suda RF. 2000. № 3; Opredelenie Konstitutsionnogo Suda RF ot 12 aprelya 2005 g. № 113-0//Rossiiskaya gazeta. 31.05.2005. № 114.

7. Panova I.V. Administrativno-protsessual'naya deyatel'nost' v Rossiiskoi Federatsii. Saratov, 2001. S.48-49.

8. Lukin V.P. Zayavlenie Upolnomochennogo po pravam cheloveka v Rossiiskoi Federatsii // Rossiiskaya gazeta. 21.10.2009. № 5023.

9. Konkurentnoe pravo Rossii: uchebnik [Tekst]/D.A. Aleshin, I.Yu. Artem'ev, E.Yu. Borzilo i dr. - M.: Izd. dom Vysshei shkoly ekonomiki, 2012. S.318.

10. Sumenkov, S. S. Antimonopol'nyi protsess kak kvazisudebnyi administrativno-yurisdiktsionnyi protsess //Biznes, Menedzhment i Pravo.-2014.-№ 1.-S.114 - 116.

11. Mikulin A.I. Printsip sostyazatel'nosti v proizvodstve po delam ob administrativnykh pravonarusheniyakh. // Administrativnoe i munitsipal'noe pravo.-2010.-10.-C. 64-72. 